\title{
Association between single nucleotide polymorphisms (SNPs) of $X R C C 2$ and $X R C C 3$ homologous recombination repair genes and triple-negative breast cancer in Polish women
}

\author{
Beata Smolarz • Marianna Makowska • \\ Dariusz Samulak $\cdot$ Magdalena M. Michalska • \\ Ewa Mojs • Maciej Wilczak $\cdot$ Hanna Romanowicz
}

Received: 23 January 2014/ Accepted: 28 March 2014/Published online: 13 April 2014

(C) The Author(s) 2014. This article is published with open access at Springerlink.com

\begin{abstract}
X R C C 2$ and $X R C C 3$ genes involved in homologous recombination repair (HRR) of DNA and in the maintenance of the genome integrity play a crucial role in protecting against mutations that lead to cancer. The aim of the present work was to evaluate associations between the risk of triple-negative breast cancer (TNBC) and polymorphisms in the genes, encoding for two key proteins of HRR: XRCC2 Arg188His (c. $563 \mathrm{G}>\mathrm{A}$; rs3218536, Genbank Accession Number NT 007914) and XRCC3 Thr241Met (c. 722 C $>$ T; rs861539, Genbank Accession Number NT 026437). The polymorphisms of the XRCC2 and $X R C C 3$ were investigated by PCR-RFLP in 70 patients
\end{abstract}

B. Smolarz $(\bowtie)$

Laboratory of Molecular Genetics, Department of Pathology,

Institute of Polish Mother's Memorial Hospital, Rzgowska

281/289, 93-338 Lodz, Poland

e-mail: smolbea@wp.pl

M. Makowska

Regional Hospital in Lodz, Lodz, Poland

D. Samulak · M. M. Michalska

Department of Obstetrics and Gynaecology, Regional Hospital in Kalisz, Kalisz, Poland

D. Samulak

Cathedral of Mother's and Child's Health, Poznan University

of Medical Sciences, Poznan, Poland

E. Mojs

Department of Clinical Psychology, Poznan University

of Medical Sciences, Poznan, Poland

M. Wilczak

Department of Medical Education, Poznan University

of Medical Sciences, Poznan, Poland

H. Romanowicz

University of Computer Sciences and Skills, Lodz, Poland with TNBC and 70 age- and sex-matched non-cancer controls. In the present work, a relationship was identified between XRCC2 Arg188His polymorphism and the incidence of triple-negative breast cancer. The $188 \mathrm{His}$ allele and 188 His/His homozygous variant increased cancer risk. An association was confirmed between XRCC2 Arg188His and XRCC3 Thr241Met polymorphisms and TNBC progression, assessed by the degree of lymph node metastases and histological grades. In conclusion, XRCC2 Arg188His and XRCC3 Thr241Met polymorphisms may be regarded as predictive factors of triple-negative breast cancer in female population.

Keywords $X R C C 2 \cdot X R C C 3 \cdot$ Triple-negative breast cancer $\cdot$ Gene polymorphism

\section{Introduction}

The term triple-negative breast cancer (TNBC) defines breast tumors that do not express estrogen receptors, progesterone receptor, or epidermal growth factor receptor HER2 on immunohistochemical analysis. TNBC refers to about $15-20 \%$ of all breast cancer cases [1-5].

Molecular profiling indicated that triple-negative breast cancer represents heterogeneous subgroup of breast cancer. Triple-negative breast cancer shares histological and genetic abnormalities with basal-like subtype of breast cancer, however, this overlap is incomplete. Triple-negative breast cancer do not benefit from hormonal therapies or treatments targeted against HER2 [1-5]. Many of targeted therapeutic agents show promise in early stage studies, but their clinical performance has yet to be definitively proven.

Molecular epidemiological studies have provided the evidence that an individual's susceptibility to precancerous 
lesions and cancer is modulated by both genetic and environmental factors [6, 7]. Genomic rearrangements (translocations, deletions, and duplications) are extremely frequent in breast cancer cells [8-11]. These rearrangements are believed to result from an aberrant repair of DNA double-strand breaks (DSBs).

Double-strand DNA breaks are the most dangerous DNA damage. If not repaired leads to down-regulation of transcription and various cancers development [12, 13]. DSB are repaired by two mechanisms: recombination (HR) and non-homologous end joining (NHEJ) [14, 15].

A recent study on the Caucasian population has provided the first epidemiological evidence, supporting the association between DSBs repair gene variants and breast cancer development [16].

Polymorphisms in DNA repair genes may alter the activity of the proteins and thus modulate cancer susceptibility [17].

RAD51 homolog (RecA homolog, E. coli) (S. cerevisi$a e)$ plays an important role in homologous recombination via, direct interaction with XRCC2 (X-ray repair crosscomplementing group 2), XRCC3 (X-ray repair crosscomplementing group 3), BRCA1 (breast cancer-1), BRCA2 (breast cancer-2), and other DNA repair proteins, to form a complex essential for repair of double-strand breaks and DNA cross-links (especially XRCC2 and $\mathrm{XRCC} 3$ ) and for the maintenance of chromosome stability [18-20].

RAD51 is involved in homologous recombination and repair of double-strand breaks in DNA and DNA crosslinks and for the maintenance of chromosome stability. $R A D 51$ gene is highly polymorphic in nature. In the literature, many reports confirm the significance $R A D 51$ gene G135C polymorphism (c. 98 G>C; rs1801320; Genbank Accession Number NT 010194), regarding the risk of breast carcinoma [21-24].

XRCC2 Arg188His polymorphism (c. $563 \mathrm{G}>\mathrm{A}$; rs3218536, Genbank Accession Number NT 007914) may limit effect on gene activity, although it can modify the breast cancer risk in female patient with low levels of plasma $\alpha$-carotene or plasma folate $[16,25]$.

The C722T substitution is the most thoroughly analyzed polymorphism in the XRCC3 gene (c. $722 \mathrm{C}>\mathrm{T}$; rs861539, Genbank Accession Number NT 026437). Although the functional relevance of $X R C C 3 \mathrm{Thr} 241 \mathrm{Met}$ variation is unknown, some studies have reported that the $722 \mathrm{~T} / \mathrm{T}$ genotype is associated with increased risk of breast cancer [26-28].

In the present study, the association between the Arg188His polymorphism of XRCC2 gene and Thr241Met polymorphism of XRCC3 gene and triplenegative breast cancer in the population of Polish women was investigated.

\section{Materials and methods}

\section{Patients}

In the reported study, paraffin-embedded tumor tissue was collected from 70 women with triple-negative breast carcinoma, treated at the Department of Oncology, Institute of Polish Mother's Memorial Hospital, Lodz, Poland. The age of the patients ranged from 36 to 68 years (the mean age $46.2 \pm 10.12$ ). No distant metastases were found in any of the patients at the time of treatment onset. The median follow-up of patients at the time of analysis was 38 months (the range 2-70 months). The average tumor size was $20 \mathrm{~mm}$ (the range 17-32 $\mathrm{mm}$ ). All the tumors were graded by a method, based on the criteria of Scarff-BloomRichardson. The demographic data and the pathologic features of the patients are summarized in Table 1. Samples from age-matched, cancer-free women $(n=70)$ served as control (the mean age $45.41 \pm 18.21$ ). Control samples consisted of DNA extracted from normal breast tissue. Normal breast specimens were obtained from patients who had undergone biopsy for benign lesions. An appropriate ethical approval was obtained from the Ethics Committee of the Institute of Polish Mother's Memorial Hospital, Lodz, Poland.

The breast tissue samples (cancerous and non-cancerous) were fixed routinely in formaldehyde, embedded in paraffin, cut into thin slices, and stained with hematoxylin/ eosin for pathological examination. DNA for analysis was obtained from an archival pathological paraffin-embedded tumor and non-cancerous breast samples which were

Table 1 Pathologic features of triple-negative breast cancer patients

\begin{tabular}{lrr}
\hline Triple-negative breast cancer & \multicolumn{2}{c}{ Patients $(n=70)$} \\
\cline { 2 - 3 } & $n$ & $(\%)$ \\
\hline Scarff-bloom-Richardson stage & 20 & 29 \\
I & 45 & 64 \\
II & 5 & 7 \\
III & & \\
Tumor size grade & 8 & 11 \\
T1 & 40 & 57 \\
T2 & 18 & 26 \\
T3 & 4 & 6 \\
T4 & & \\
Lymph node status & 32 & 46 \\
N0 & 12 & 17 \\
N1 & 14 & 20 \\
N2 & 7 & 10 \\
N3 & 5 & 7 \\
N4 & &
\end{tabular}


Table 2 Primer sequences for polymerase chain reaction (PCR) analysis

\begin{tabular}{lll}
\hline & Primer sequence & $\begin{array}{c}\text { PCR fragment } \\
\text { length (bp) }\end{array}$ \\
\hline XRCC2 & $\begin{array}{l}\text { forward 5'-TGTAGTCACCCATCTCTCTGC-3' } \\
\text { reverse 5'-AGTTGCTGCCATGCCTTACA-3' } \\
\text { forward 5'-GCCTGGTGGTCATCGACTC-3' } \\
\text { XRCC3 }\end{array}$ & 290 \\
& reverse 5'-ACAGGGCTCTGGAAGGCACTGCTCAGCTCACGCACC-3' & 552 \\
\hline
\end{tabular}

deparaffinized in xylene and rehydrated in ethanol and distilled water. In order to ensure that the chosen histological material is representative for cancerous and noncancerous tissue, every tissue sample qualified for DNA extraction was initially checked by a pathologist. DNA was extracted from material using commercially available QIAmp Kit (Qiagen GmbH, Hilden, Germany) DNA purification kit according to manufacturer's instruction.

\section{Genotyping}

Polymorphism of XRCC2 and XRCC3 gene was determined by PCR-RFLP (polymerase chain reaction-restriction fragment length polymorphism), using the appropriate primers (Table 2).

\section{Determination of XRCC2 genotype}

The $25 \mu \mathrm{L}$ PCR mixture contained $100 \mathrm{ng}$ of DNA, $12.5 \mathrm{pmol}$ of each primer, $0.2 \mathrm{mmol} / \mathrm{l}$ of dNTPs, $2 \mathrm{mmol} / \mathrm{l}$ of $\mathrm{MgCl}_{2}$, and $1 \mathrm{U}$ of Taq DNA polymerase. Thermal cycling conditions were as follows: initial denaturation step at $94{ }^{\circ} \mathrm{C}, 30$ cycles at $94{ }^{\circ} \mathrm{C}$ for $30 \mathrm{~s}$, and $30 \mathrm{~s}$ at $60^{\circ} \mathrm{C}$ annealing temperature, and at $72{ }^{\circ} \mathrm{C}$ for $1 \mathrm{~min}$. The final extension was performed at $72{ }^{\circ} \mathrm{C}$ for $7 \mathrm{~min}$. The $290 \mathrm{bp}$ amplified product was digested overnight with $1 \mathrm{U}$ of $\mathrm{HpnI}$ (New England Biolabs, Ipswich, MA, USA) at $37^{\circ} \mathrm{C}$. The wild-type allele Arg was identified by the presence of single band of $290 \mathrm{bp}$, while the mutant allele His was represented by 148 and 142 bp bands.

\section{Determination of XRCC3 genotype}

XRCC3 gene polymorphism was determined by PCRRFLP, using codon 241 primers. The $25 \mu \mathrm{L}$ PCR mixture contained $100 \mathrm{ng}$ of DNA, $12.5 \mathrm{pmol}$ of each primer, $0.2 \mathrm{mmol} / \mathrm{l}$ of dNTPs, $2 \mathrm{mmol} / \mathrm{l}$ of $\mathrm{MgCl}_{2}$, and $1 \mathrm{U}$ of Taq DNA polymerase. Thermal cycling conditions were the following: $94{ }^{\circ} \mathrm{C}$ for $60 \mathrm{~s}, 56{ }^{\circ} \mathrm{C}$ for $30 \mathrm{~s}$, and then $72{ }^{\circ} \mathrm{C}$ for $40 \mathrm{~s}$, repeated in 30 cycles. The $552 \mathrm{bp}$ amplified product was digested overnight with $5 \mathrm{U}$ of NlaIII (New England Biolabs, Ipswich, MA, USA) at $37{ }^{\circ} \mathrm{C}$. The wildtype allele Thr was identified by the presence of two 239 and 313 bp bands, while the mutant allele Met was represented by 105,208 , and 239 bp bands.
Statistical analysis

Genotype frequency deviations were assessed for each polymorphism, comparing Hardy-Weinberg equilibrium values with control values by the standard Chi square test. Genotype frequencies in the study cases and the controls were compared by the Chi square test. Genotype specific risks were estimated as odds ratios (ORs) with associated $95 \%$ intervals (CIs) by unconditional logistic regression. $p$ values $<0.05$ were considered significant. All the statistical analyses were performed, using the STATISTICA 6.0 software (Statsoft, Tulsa, OK, USA).

\section{Results}

The genotype frequency of the XRCC2 Arg188His polymorphism in the TNBC patients and controls is summarized in Table 3. It can be seen from the Table that there are significant differences in the frequency of genotypes $(p<0.05)$ between the two investigated groups. A weak association was observed between triple-negative breast carcinoma occurrence and the presence of at least one 188 His allele. A stronger association was observed for $188 \mathrm{His} / \mathrm{His}$ than for $188 \mathrm{Arg} / \mathrm{His}$ heterozygous variant. In case of the Arg188His polymorphism of XRCC2 gene, the distribution of the genotypes in the patients differed significantly from one expected from the Hardy-Weinberg equilibrium $(p<0.05)$.

No statistically significant differences were observed in genotype frequencies of XRCC3 Thr241Met polymorphism between the control group and the TNBC patients (see Table 4). Among the patients, all genotype distributions did not differ significantly $(p>0.05)$ from those expected by the Hardy-Weinberg equilibrium.

Histological grading was related to XRCC2 Arg188His and the XRCC3 Thr241Met polymorphisms. Histological stages were evaluated in all the cases $(n=70)$. There were as follows: stage I-20 cases, stage II -45 cases, and stage III -5 cases. Stages II and III were accounted together for statistical analysis (see Table 5). Some correlation was observed between the XRCC2-Arg188His and XRCC3Thr241Met polymorphisms and triple-negative breast cancer invasiveness. An increase was observed, regarding $188 \mathrm{Arg} / \mathrm{His}$ heterozygotes frequency (OR 2.45; $95 \%$ CI 
Table 3 Distribution of 188Arg/Arg, 188Arg/His, and 188His/His genotypes and frequencies of the Arg and His alleles in patients with triplenegative breast cancer and controls

\begin{tabular}{|c|c|c|c|c|c|c|}
\hline \multirow[t]{2}{*}{ XRCC2 Arg188His } & \multicolumn{2}{|c|}{ TNBC patients $(n=70)$} & \multicolumn{2}{|c|}{ Controls $(n=70)$} & \multirow[t]{2}{*}{ OR $(95 \% \mathrm{CI})^{\mathrm{a}}$} & \multirow[t]{2}{*}{$p^{\mathrm{b}}$} \\
\hline & Number & $(\%)$ & Number & $(\%)$ & & \\
\hline 188Arg/Arg & 12 & 17 & 18 & 26 & $1.00 \mathrm{Ref}$ & \\
\hline $188 \mathrm{Arg} / \mathrm{His}$ & 8 & 12 & 40 & 57 & $0.30(0.10-0.86)$ & 0.042 \\
\hline 188His/His & 50 & 71 & 12 & 17 & $6.25(2.38-16.39)$ & 0.0003 \\
\hline 188Arg & 32 & 23 & 76 & 54 & $1.00 \mathrm{Ref}$ & \\
\hline $188 \mathrm{His}$ & 108 & 77 & 64 & 46 & $4.00(2.39-6.71)$ & $<.0001$ \\
\hline
\end{tabular}

Data in boldface are statistically significant $(p<0.05)$

${ }^{\text {a }}$ Crude odds ratio (OR), $95 \% \mathrm{CI}=$ confidence interval at $95 \%$

b Chi square

Table 4 Distribution of 241Thr/Thr, 241Thr/Met, and 241Met/Met genotypes and frequencies of the Thr and Met alleles in patients with triplenegative breast cancer and controls

\begin{tabular}{|c|c|c|c|c|c|c|}
\hline \multirow[t]{2}{*}{ XRCC3 Thr241Met } & \multicolumn{2}{|c|}{ TNBC patients $(n=70)$} & \multicolumn{2}{|c|}{ Controls $(n=70)$} & \multirow[t]{2}{*}{ OR $(95 \% \mathrm{CI})^{\mathrm{a}}$} & \multirow[t]{2}{*}{$p^{\mathrm{b}}$} \\
\hline & Number & $(\%)$ & Number & $(\%)$ & & \\
\hline 241Thr/Thr & 19 & 27 & 15 & 21 & $1.00 \operatorname{Ref}$ & \\
\hline 241Thr/Met & 35 & 49 & 35 & 50 & $0.78(0.34-1.79)$ & 0.718 \\
\hline 241Met/Met & 16 & 23 & 20 & 29 & $0.63(0.24-1.62)$ & 0.475 \\
\hline 241Thr & 73 & 52 & 65 & 46 & 1.00 Ref & \\
\hline 241Met & 67 & 48 & 75 & 54 & $0.79(0.49-1.27)$ & 0.402 \\
\hline
\end{tabular}

${ }^{\text {a }}$ Crude odds ratio (OR), $95 \% \mathrm{CI}=$ confidence interval at $95 \%$

b Chi square

0.66-9.02, $p=0.289$ ) and 241Thr/Met heterozygotes (OR $2.50 ; 95 \%$ CI $0.68-9.11, p=0.267)$ in stage I patients, according to Scarff-Bloom-Richardson classification. That increase was, however, not statistically significant.

Table 6 shows the distribution of genotypes and the frequency of alleles in patients with $(\mathrm{N}+)$ and without (N-) lymph node metastases. A tendency for a decreased risk of breast cancer was observed with the occurrence of $188 \mathrm{His} / \mathrm{His}$ genotype and $188 \mathrm{His}$ allele of XRCC2 and 241Met/Met genotype and 241Met allele of XRCC3 polymorphism. That decrease was, however, not statistically significant $(p>0.05)$ (see Table 6). There were no differences either in the distribution of genotypes or the frequency of alleles in the group of patients with different tumor size (Table 6).

\section{Discussion}

According to our data, it is the first time that polymorphisms in XRCC2 and XRCC3 genes involved in the DNA repair pathway were analyzed in the population of Polish women with TNBC. The combined effect of XRCC2 and $X R C C 3$ polymorphisms on TNBC occurrence was not investigated before. The study was performed on an ethnically homogenous population, which may improve our knowledge, regarding to what an extent the genotypephenotype relationship variations are population-related.

The polymorphisms, chosen for the study, had previously been shown to have functional significance and to be responsible factors for low DNA repair capacity phenotype, characteristic for patients with cancer including those with breast carcinoma [20].

The genes involved in DNA repair and in the maintenance of genome integrity play a crucial role in providing protection against mutations that may lead to cancer [29].

XRCC2 and XRCC3 proteins are structurally and functionally related to RAD51, which plays an important role in the homologous recombination, the process being frequently involved in cancer transformation [30].

$R A D 51, X R C C 2$, and $X R C C 3$ gene are highly polymorphic. A single nucleotide polymorphism, 135G/C, has been identified in the $5^{\prime}$ untranslated region of the RAD51 gene and has been shown to influence gene transcription activity [31]. As it was mentioned in the Introduction above, the reports on the relationship between $R A D 51$ G135C polymorphism and breast cancer incidence are suggest that the RAD51 $135 \mathrm{C}$ variant allele was associated 
Table 5 Dependence of genotypes and frequencies of $X R C C 2$ and $X R C C 3$ gene polymorphism alleles on tumor stage in triple-negative breast cancer patients ${ }^{\mathrm{a}}$

${ }^{\text {a }} n=70$

b according to scarff-bloomRichardson criteria

c crude odds ratio (OR), $95 \%$ $\mathrm{CI}=$ confidence interval at $95 \%$

d chi square

Table $6 \mathrm{XRCC2}$ and $\mathrm{XRCC} 3$ gene polymorphism and triplenegative breast cancer progression $^{\mathrm{a}}$ a $\mathrm{T} 2$ versus $\mathrm{T} 3+\mathrm{T} 4$

${ }^{\mathrm{b}} \mathrm{N}-$ (node negative) versus $\mathrm{N}+$ (node positive)

\begin{tabular}{|c|c|c|c|c|}
\hline \multirow[t]{2}{*}{ Stage $^{b}$} & \multicolumn{4}{|c|}{ Triple-negative breast cancer patients } \\
\hline & $\mathrm{I}(n=20)$ & $\mathrm{II}+\mathrm{III}(n=50)$ & OR $(95 \% \mathrm{CI})^{\mathrm{c}}$ & $p^{\mathrm{d}}$ \\
\hline \multicolumn{5}{|c|}{ XRCC2 Arg188His } \\
\hline 188Arg/Arg & $4(20)$ & $14(28)$ & $1.00 \mathrm{Ref}$ & \\
\hline $188 \mathrm{Arg} / \mathrm{His}$ & $14(70)$ & $20(40)$ & $2.45(0.66-9.02)$ & 0.289 \\
\hline 188His/His & $2(10)$ & $16(32)$ & $1.09(0.29-4.08)$ & 0.588 \\
\hline 188Arg & $22(55)$ & $48(48)$ & $1.00 \mathrm{Ref}$ & \\
\hline 188 His & $18(45)$ & $52(52)$ & $0.76(0.36-1.57)$ & 0.571 \\
\hline \multicolumn{5}{|c|}{ XRCC3 Thr241Met } \\
\hline 241Thr/Thr & $4(20)$ & $15(30)$ & $1.00 \mathrm{Ref}$ & \\
\hline 241Thr/Met & $14(70)$ & $21(42)$ & $2.50(0.68-9.11)$ & 0.267 \\
\hline 241Met/Met & $2(10)$ & $14(28)$ & $0.53(0.08-3.39)$ & 0.417 \\
\hline $241 \mathrm{Thr}$ & $22(55)$ & $51(51)$ & $1.00 \mathrm{Ref}$ & \\
\hline 241Met & $18(45)$ & 49 (49) & $0.85(0.40-1.77)$ & 0.806 \\
\hline
\end{tabular}

\begin{tabular}{|c|c|c|c|c|c|c|}
\hline \multicolumn{7}{|c|}{ XRCC2 Arg188His } \\
\hline 188Arg/Arg & $8(36)$ & $17(35)$ & $1.00 \operatorname{Ref}$ & $12(32)$ & $10(31)$ & 1.00 Ref \\
\hline 188Arg/His & $8(36)$ & $18(38)$ & $2.51(0.57-11.1)$ & $16(42)$ & $11(34)$ & $1.21(0.38-3.78)$ \\
\hline $188 \mathrm{His} / \mathrm{His}$ & $6(28)$ & $13(27)$ & $2.61(0.54-12.3)$ & $10(26)$ & $11(34)$ & $0.75(0.22-2.51)$ \\
\hline 188Arg & $24(55)$ & $52(54)$ & $1.00 \mathrm{Ref}$ & $40(53)$ & $31(48)$ & $1.00 \mathrm{Ref}$ \\
\hline $188 \mathrm{His}$ & $20(45)$ & $44(46)$ & $0.98(0.48-2.01)$ & $36(47)$ & $33(52)$ & $0.84(0.43-1.64)$ \\
\hline \multicolumn{7}{|c|}{ XRCC3 Thr241Met } \\
\hline 241Thr/Thr & $7(32)$ & $17(35)$ & 1.00 Ref & $13(35)$ & $10(31)$ & $1.00 \mathrm{Ref}$ \\
\hline 241Thr/Met & $9(41)$ & $19(40)$ & $1.15(0.35-3.76)$ & $15(39)$ & $10(31)$ & $1.15(0.36-3.64)$ \\
\hline $\begin{array}{l}\text { 241Met/ } \\
\text { Met }\end{array}$ & $6(27)$ & $12(25)$ & $1.21(0.32-4.53)$ & $10(26)$ & $12(38)$ & $0.64(0.19-2.07)$ \\
\hline $241 \mathrm{Thr}$ & $23(52)$ & $53(55)$ & 1.00 Ref & $41(54)$ & $30(47)$ & $1.00 \mathrm{Ref}$ \\
\hline $241 \mathrm{Met}$ & $21(48)$ & $43(45)$ & $1.12(0.55-2.30)$ & $35(46)$ & $34(53)$ & $0.75(0.38-1.46)$ \\
\hline
\end{tabular}

with an increased risk of female breast cancer [22, 23, 32, 33].

By contrast, Brooks et al. [34] showed that RAD51 gene variants were found to be not associated with breast cancer risk.

Other studies have shown that the RAD51 135C variant allele was associated with an increased risk of female breast cancer [35-37].

$135 \mathrm{C} / \mathrm{C}$ genotype may be associated with an elevated tumor risk among the European populations, regarding sporadic breast cancer [36]. Similar results were obtained in the Polish population [38].

In our earlier study, RAD51 135C allele variant was associated with an elevated risk of triple-negative breast cancer in the Polish women [39].

It is possible that the presence of $\mathrm{C}$ allele remains in a linkage disequilibrium with another, so far unknown, mutation located outside the coding region in the RAD51 gene, which may be important, regarding RAD51 concentrations in plasma.

In the presented study, XRCC2 Arg188His genotype was associated with an elevated risk of triple-negative breast cancer in the Polish population. There was a 6.25-fold increased risk of TNBC for the individuals, carrying XRCC2-188His/His genotype, compared with subjects carrying XRCC2-188Arg/Arg, 188Arg/His genotype, respectively. XRCC2 Arg188His polymorphism was not related, either to tumor size or cancer type or grade.

In the reported study, the Arg188His polymorphism of XRCC2 gene and Thr241Met of XRCC3 were correlated with breast carcinoma progression. Arg188His and Thr241Met heterozygote were associated with an increased risk of stage I breast cancer. 
However, other literature data were also found [40-42]. No significant associations were observed between the Thr241Met and breast cancer in Iowa and Cypriot women $(40,43)$.

In the Polish population, Thr241Met genotype of $X R C C 3$ polymorphism increased the risk of breast cancer development [41, 42, 44].

Similar to our observation, the recent reports demonstrate that XRCC3 Thr241Met allele seems associated with an elevated breast cancer risk in non-Chinese subjects (28).

The role of position 188 in the aminoacid chain for XRCC2 protein functionality is still unknown. The several data suggest that XRCC2 Arg188His polymorphism is not directly associated with breast cancer risk [45, 46].

In conclusion, the reported study is another evidence for the significance of Thr241Met and Arg188His genotype in breast carcinoma staging.

The obtained data show that Arg188His and Thr241Met polymorphisms of $X R C C 2 / 3$ genes may be associated with the risk of triple-negative breast carcinoma occurrence. On the other hand, a protective effect was observed of all the polymorphisms in the patients without $(\mathrm{N}-)$ lymph node metastasis. The obtained data suggest that the reported study may be the first observation of the polymorphisms in $X R C C 2$ and $X R C C 3$ genes, involved in the DNA repair pathway, to be associated with triple-negative breast carcinoma risk in the population of Polish women.

Finally, it is postulated that these polymorphisms may be used as predictive factors for TNBC in the Polish female population. Further studies, conducted on a larger group, are suggested to clarify this point.

Conflict of interest The authors declare no conflict of interest.

Open Access This article is distributed under the terms of the Creative Commons Attribution License which permits any use, distribution, and reproduction in any medium, provided the original author(s) and the source are credited.

\section{References}

1. Bauer KR, Brown M, Cress RD, Parise CA, Caggiano V (2007) Descriptive analysis of estrogen receptor (ER)-negative, progesterone receptor (PR)-negative, and HER2-negative invasive breast cancer, the socalled triple-negative phenotype: a population-based study from the California cancer registry. Cancer 109:1721-1728

2. Chacón RD, Costanzo MV (2010) Triple-negative breast cancer. Breast Cancer Res 12:S3

3. Cleator S, Heller W, Coombes RC (2007) Triple-negative breast cancer: therapeutic options. Lancet Oncol 8:235-244

4. Dawson SJ, Provenzano E, Caldas C (2009) Triple negative breast cancers: clinical and prognostic implications. Eur J Cancer 45:27-40

5. de Ruijter TC, Veeck J, de Hoon JP, van Engeland M, TjanHeijnen VC (2011) Characteristics of triple-negative breast cancer. J Cancer Res Clin Oncol 137:183-192
6. Nair UJ, Nair J, Mathew B, Bartsch H (1999) Glutathione S-transferase M1 and T1 null genotypes as risk factors for oral leukoplakia in ethnic Indian betel quid/tobacco chewers. Carcinogenesis 20:743-748

7. Sikdar N, Paul RR, Roy B (2004) Glutathione S-transferase M3 (A/A) genotype as a risk factor for oral cancer and leukoplakia among Indian tobacco smokers. Int J Cancer 109:95-101

8. Davidson JM, Gorringe KL, Chin SF, Orsetti B, Besret C, Courtay-Cahen C, Roberts I, Theillet C, Caldas C, Edwards PA (2000) Molecular cytogenetic analysis of breast cancer cell lines. Br J Cancer 83:1309-1317

9. Forozan F, Mahlamaki EH, Monni O, Chen Y, Veldman R, Jiang Y, Gooden GC, Ethier SP, Kallioniemi A, Kallioniemi OP (2000) Comparative genomic hybridization analysis of 38 breast cancer cell lines: a basis for interpreting complementary DNA microarray data. Cancer Res 60:4519-4525

10. Kytola S, Rummukainen J, Nordgren A, Karhu R, Farnebo F, Isola J, Larsson C (2000) Chromosomal alterations in 15 breast cancer cell lines by comparative genomic hybridization and spectral karyotyping. Genes Chromosomes Cancer 28:308-317

11. Loveday RL, Greenman J, Simcox DL, Speirs V, Drew PJ, Monson JR, Kerin MJ (2000) Genetic changes in breast cancer detected by comparative genomic hybridisation. Int $\mathrm{J}$ Cancer 86:494-500

12. Vijg J, Dolle MET (2002) Large genome rearrangements as a primary cause of aging. Mech Ageing Dev 123:907-915

13. Bahar R, Hartmann CH, Rodriguez KA, Denny AD, Busuttil RA, Dolle ME, Calder RB, Chisholm GB, Pollock BH, Klein CA, Vijg J (2006) Increased cell-to-cell variation in gene expression in ageing mouse heart. Nature 441:1011-1014

14. Jackson SP (2002) Sensing and repairing DNA double-strand breaks. Carcinogenesis 23:687-696

15. Helleday T (2003) Pathways for mitotic homologous recombination in mammalian cells. Mutat Res 532:103-115

16. Silva SN, Tomar M, Paulo C, Gomes BC, Azevedo AP, Teixeira V, Pina JE, Rueff J, Gaspar JF (2010) Breast cancer risk and common single nucleotide polymorphisms in homologous recombination DNA repair pathway genes XRCC2, XRCC3, NBS1 and RAD51. Cancer Epidemiol 34:85-92

17. Lunn RM, Langlois RG, Hsieh LL, Thompson CL, Bell DA (1999) XRCC1 polymorphisms: effects on aflatoxin B1-DNA adducts and glycophorin a variant frequency. Cancer Res 59:2557-2561

18. Kennedy RD, D'Andrea AD (2005) The fanconi anemia/BRCA pathway: new faces in the crowd. Genes Dev 19:2925-2940

19. San Filippo J, Sung P, Klein H (2008) Mechanism of eukaryotic homologous recombination. Annu Rev Biochem 77:229-257

20. Thacker J (2005) The RAD51 gene family, genetic instability and cancer. Cancer Lett 219:125-135

21. Wang W, Li JL, He XF, Li AP, Cai YL, Xu N, Sun SM, Wu BY (2013) Association between the RAD51 $135 \mathrm{G}>\mathrm{C}$ polymorphism and risk of cancer: a meta-analysis of 19,068 cases and 22,630 controls. PLoS One 8:e75153

22. Hosseini M, Houshmand M, Ebrahimi A (2013) RAD51 polymorphisms and breast cancer risk. Mol Biol Rep 40:665-668

23. Romanowicz-Makowska H, Smolarz B, Zadrozny M, Westfa B, Baszczyński J, Kokołaszwili G, Burzyfiski M, Połać I, Sporny S (2012) The association between polymorphisms of the RAD51G135C, XRCC2-Arg188His and XRCC3-Thr241Met genes and clinico-pathologic features in breast cancer in Poland. Eur $\mathrm{J}$ Gynaecol Oncol 33:145-150

24. Kadouri L, Kote-Jarai Z, Hubert A, Durocher F, Abeliovich D, Glaser B, Hamburger T, Eeles RA, Peretz T (2004) A singlenucleotide polymorphism in the RAD51 gene modifies breast cancer risk in BRCA2 carriers, but not in BRCA1 carriers or noncarriers. Br J Cancer 90:2002-2005 
25. Han J, Hankinson SE, Zhang SM (2004) Interaction between genetic variations in DNA repair genes and plasma folate on breast cancer risk. Cancer Epidemiol Biomarkers Prev 13:520-524

26. Costa S, Pinto D, Pereira D, Rodrigues H, Cameselle-Teijeiro J, Medeiros R, Schmitt F (2007) DNA repair polymorphisms might contribute differentially on familial and sporadic breast cancer susceptibility: a study on a Portuguese population. Breast Cancer Res Treat 103:209-217

27. Sangrajrang S, Schmezer P, Burkholder I, Boffetta P, Brennan P, Woelfelschneider A, Bartsch H, Wiangnon S, Cheisilpa A, Popanda O (2007) The XRCC3 Thr241Met polymorphism and breast cancer risk: a case control study in a Thai population. Biomarkers 12:523-532

28. Economopoulos KP, Sergentanis TN (2010) XRCC3 Thr241Met polymorphism and breast cancer risk: a meta-analysis. Breast Cancer Res Treat 121:439-443

29. Jiricny J, Nystrom-Lahti M (2000) Mismatch repair defects in cancer. Curr Opin Genet Dev 10:157-161

30. Kuschel B, Auranen A, McBride S, Novik KL, Antoniou A, Lipscombe JM, Day NE, Easton DF, Ponder BA, Pharoah PD, Dunning A (2002) Variants in DNA double-strand break repair genes and breast cancer susceptibility. Hum Mol Genet 11:1399-1407

31. Hasselbach L, Haase S, Fischer D, Kolberg HC, Stürzbecher HW (2005) Characterisation of the promoter region of the human DNA-repair gene RAD51. Eur J Gynaecol Oncol 26:589-598

32. Dufloth RM, Arruda A, Heinrich JK, Schmitt F, Zeferino LC (2008) The investigation of DNA repair polymorphisms with histopathological characteristics and hormone receptors in a group of Brazilian women with breast cancer. Genet Mol Res 7:574-582

33. Jara L, Dubois K, Gaete D, de Mayo T, Ratkevicius N, Bravo T, Margarit S, Blanco R, Gómez F, Waugh E, Peralta O, Reyes JM, Ibáñez G, González-Hormazábal P (2010) Variants in DNA double-strand break repair genes and risk of familial breast cancer in a South American population. Breast Cancer Res Treat 122:813-822

34. Brooks J, Shore RE, Zeleniuch-Jacquotte A, Currie D, Afanasyeva Y, Koenig KL, Arslan AA, Toniolo P, Wirgin I (2008) Polymorphisms in RAD51, XRCC2, and XRCC3 are not related to breast cancer risk cancer epidemiol. Biomarkers Prev 17:1016-1019

35. Jara L, Acevedo ML, Blanco R, Castro VG, Bravo T, Gómez F, Waugh E, Peralta O, Cabrera E, Reyes JM, Ampuero S, González-Hormazábal P (2007) RAD51 135G >C polymorphism and risk of familial breast cancer in a South American population. Cancer Genet Cytogenet 178:65-69
36. Gao LB, Pan XM, Li LJ, Liang WB, Zhu Y, Zhang LS, Wei YG, Tang M, Zhang L (2011) RAD51 135G/C polymorphism and breast cancer risk: a meta-analysis from 21 studies. Breast Cancer Res Treat 125:827-835

37. Wang Z, Dong H, Fu Y, Ding H (2010) RAD51 135G $>$ C polymorphism contributes to breast cancer susceptibility: a metaanalysis involving 26,444 subjects. Breast Cancer Res Treat 124:765-769

38. Synowiec E, Stefanska J, Morawiec Z, Blasiak J, Wozniak K (2008) Association between DNA damage, DNA repair genes variability and clinical characteristics in breast cancer patients. Mutat Res 648:65-72

39. Smolarz B, Zadrożny M, Duda-Szymańska J, Makowska M, Samulak D, Michalska MM, Mojs E, Bryś M, Forma E, Romanowicz-Makowska H (2013) RAD51 genotype and triplenegative breast cancer (TNBC) risk in Polish women. Pol J Pathol 64:39-43

40. Loizidou MA, Michael T, Neuhausen SL, Newbold RF, Marcou Y, Kakouri E, Daniel M, Papadopoulos P, Malas S, Kyriacou K, Hadjisavvas A (2008) Genetic polymorphisms in the DNA repair genes XRCC1, XRCC2 and XRCC 3 and risk of breast cancer in Cyprus. Breast Cancer Res Treat 112:575-579

41. Krupa R, Synowiec E, Pawlowska E, Morawiec Z, Sobczuk A, Zadrozny M, Wozniak K, Blasiak J (2009) Polymorphism of the homologous recombination repair genes RAD51 and XRCC3 in breast cancer. Exp Mol Pathol 87:32-35

42. Sobczuk A, Romanowicz-Makowska H, Fiks T, Baszczyński J, Smolarz B (2009) XRCC1 and XRCC3 DNA repair gene polymorphisms in breast cancer women from the Lodz region of Poland. Pol J Pathol 60:76-80

43. Thyagarajan B, Anderson KE, Folsom AR, Jacobs DR Jr, Lynch CF, Bargaje A, Khaliq W, Gross MD (2006) No association between XRCC1 and XRCC3 gene polymorphisms and breast cancer risk: Iowa women's health study. Cancer Detect Prev 30:313-321

44. Romanowicz-Makowska H, Smolarz B, Zadrozny M, Westfal B, Baszczynski J, Polac I, Sporny S (2011) Single nucleotide polymorphisms in the homologous recombination repair genes and breast cancer risk in Polish women. Tohoku J Exp Med 224:201-208

45. Rafii S, O’Regan P, Xinarianos G, Azmy I, Stephenson T, Reed M, Meuth M, Thacker J, Cox A (2002) A potential role for the XRCC2 R188H polymorphic site in DNA-damage repair and breast cancer. Hum Mol Genet 11:1433-1438

46. Yu KD, Chen AX, Qiu LX, Fan L, Yang C, Shao ZM (2010) XRCC2 Arg188His polymorphism is not directly associated with breast cancer risk: evidence from 37,369 subjects. Breast Cancer Res Treat 123:219-225 